\title{
Twenty Four Approaches for Conservation of Non-Orthodox Agricultural Plant Genetic Resources in Nepal
}

\author{
Bal Krishna Joshi
}

National Agriculture Genetic Resources Center (National Genebank), NARC, Khumaltar, Lalitpur, PO Box 3055, Kathmandu, Nepal; @: joshibalak@yahoo.com; ORCID: http://orcid.org/0000-0002-7848-5824

Received 14 Aug 2018, Revised 8 Sept 2019, Accepted 25 Jan 2019, Published 28 April 2019

Scientific Editors: Jiban Shrestha, Krishna H. Ghimire, Umesh K. Acharya

Copyright $\odot 2019$ NARC. Permits unrestricted use, distribution and reproduction in any medium provided the original work is properly cited.

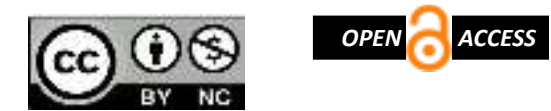

Licensed under the Creative Commons AttributionNonCommercial 4.0 International (CC BY-NC 4.0)

\begin{abstract}
The conservation of plant genetic diversity underpins the future of agriculture, food and nutrition security and is critical to ensure the ability of future generations to cope with global environmental changes. The conservation efforts were more focused on orthodox crop species in Nepal before 2010. About $40 \%$ of agricultural plant genetic resources are non-orthodox, either recalcitrant/ intermediate type or vegetatively propagated plant species. Approaches for conservation of non-orthodox plant species differ from that of orthodox crops. Different conservation approaches have been established by National Agriculture Genetic Resources Center, Nepal for conserving non-orthodox agricultural plant species. We applied household survey, literatures survey, field survey, key informant survey and organized focus group discussion for assessing the different conservation approaches. A total of 24 approaches are being considered for conservation of non-orthodox plant species. Approaches under the ex-situ strategy are field genebank, botanical garden, city park, government farm, religious place, in-vitro culture and evolutionary plant breeding; under on-farm strategy are community field genebank, school field genebank, household field genebank, community/ public orchard, village level field genebank, geographical indication and participatory landrace enhancement, and under in-situ strategy are protected area, Ramsar site, world heritage site, community forest and legal protection for conserving nonorthodox plant species in Nepal. Field genebank is the very good approach, and it has been established in about 20 research stations. It should be extended to government farms and agriculture offices to conserve the local APGRs available in their respective command areas. Databases (passport and characterization) have been generated and will be available online to enhance the utilization in breeding, research and production.
\end{abstract}

Keywords: Conservation, ex-situ, field genebank, in-situ, on-farm, recalcitrant, vegetatively propagated plants

\section{सारांश}

नेपालमा वि.सं. २०६७ साल अगाडिसम्म संरक्षण कार्य मुख्यत: सुकाएर बिउ राख्न सकिने जात तथा प्रजातिहरुमा भएको पाइन्छ, करिब $४ ० \%$ बनस्पतिको प्रजातिहरु बिउ सुकाएर राख्न नसकिने खालका छन् । जस अन्तर्गत बिउ नै उत्पादन नहुने जातहरु र बिउ उत्पादन भए पनि धेरै सुकाउन नहुने जातहरु पर्दछन्। यस्ता जातहरुको संरक्षण विधि, बिउ सुकाएर राख्न सकिने जातको भन्दा फरक हुन्छ। यस्ता जातहरुको संरक्षणको लागि राष्ट्रिय कृषि आनुवांशिक स्रोत केन्द्रले विभिन्न तरिकाहरु अपनाएको छ। देशमा के कस्ता यस्ता तरिकाहरु छन् भनेर विभिन्न ठाउँहरुमा घर सर्भे, प्रकाशन अध्ययन, फिल्ड भ्रमण तथा सर्भे, मुख्य अनुभवी व्यक्ति सर्भेको साथै सम्बन्धित समूहमा छलफल कार्य गरियो। जम्मा २४ विभिन्न तरिकाहरु मार्फत यस्ता जातहरु संरक्षण गरिएको पाइयो। परस्थानिय संरक्षण रणनीति अन्तर्गत अपनाइएको संरक्षण तरिकाहरुमा फिल्ड जिन बैंक, वनस्पति उद्यान, शहरी पार्क, सरकारी फार्म, धार्मिक स्थल, तन्तु प्रविधि तथा उत्परिवर्तित बाली प्रजनन छन् भने घर गोठ स्तरिय फिल्ड जिन बैंक, भौगोलिक सूचक तथा सहभागिता मूलक जातीय सुधार छन् । स्थानीय रणनीति अन्तर्गत संरक्षित क्षेत्र, सिमसार क्षेत्र, विश्व सम्पदा क्षेत्र, सामुदायिक बन र प्रजातिमा बन्देज जस्ता तरिकाहरुबाट संरक्षण कार्य भइरहेको छ। फिल्ड जिन बैंक सबैभन्दा राम्रो, सजिलो र प्रभावकारी तरिकाको रुपमा पाइनुका साथै यसका विभिन्न तरिकाबाट प्रयोग भएको देखिन्छ । नेपाल कृषि अनुसन्धान परिषद्को करिब ३० वटा अनुसन्धान केन्द्रहरुमा फिल्ड जिन बैंक स्थापना भएको छ। आ-आफ्नो कार्य क्षेत्रमा पाइने स्थानीय जातहरु संरक्षणको लागि अन्य सरकारी कार्यंलयहरुमा फिल्ड जिन बैंकको स्थापना गर्नु पर्दछ। यसरी संक्षित स्रोतहरुको केही पासपोर्ट र चारित्रिक आंकडाहरु तयारी गरिएको छ र यस्ता आंकडाहरु Online खोज मार्फत व्यवस्था गर्नु पर्ने देखिन्छ। 


\section{INTRODUCTION}

Agricultural plant genetic resources (APGRs) are most important for food and nutrition security. The numbers of food value plant species are 790 and cultivated are 577 including forage species in Nepal (Joshi et al 2017a, MoFSC 2014, Upadhyay and Joshi 2003). Among 577 cultivated species; 484 are indigenous and 93 are introduced species. About 224 wild species are closely related to crops (called crop wild relatives). The estimated numbers of crop landraces are 30,000 (Joshi et al 2017a). Three broad groups of APGRs are agronomic crops, horticultural crops and forages and numbers of known species under these groups are 64, 145 and 275 respectively. Nepal experiences six seasons. A wide range of climate from sub tropical to temperate and alpine cold semi desert are the main reason for existing diverse crop gene pools in the country. Crop cultivation ranges from $60 \mathrm{~m}$ (Kechana Kalan, Jhapa) to $4700 \mathrm{~m}$ (Khumbu, Solukhumbu) altitude (Joshi 2017a). Eight agro-ecosystems available in the country are rainfed High Hill, rainfed Mid Hill, rainfed Tarai, irrigated High Hill, irrigated Mid Hill, irrigated Tarai, wetland agriculture and rangeland agriculture.

Before 2010, major focus was on conservation of orthodox crops. More than 10,000 accessions of orthodox crop species have been conserved in NAGRC (Genebank 2016). More than 21 countries (USA, Japan, UK, Sweden, Germany, Italy, Syria, India, China, Philippines, Australia, Mexico, etc) have also conserved seeds of Nepalese APGRs totaling about more than 23,600 accessions, which are of orthodox types (Joshi et al 2016). There are 60\% orthodox crops in Nepal. Orthodox seeds (eg rice, maize, bean, etc) are long-lived seeds and can be successfully dried to moisture contents of 3-7\% without injury and are able to tolerate freezing. Orthodox seeds are therefore, also termed as desiccation tolerant seeds. Recalcitrant seeds including intermediate types (eg mango, litchi, coffee, citrus, etc) are remarkably short-lived which cannot be dried to moisture content below 12-30\% without injury and are unable to tolerate freezing. Recalcitrant seeds are therefore, also termed as desiccation sensitive seeds (Hong et al 1996). The third category is those plant species which do not produce seeds (if produced, not effective to regenerate) and need vegetative parts to regenerate. eg, banana, potato, ginger, etc. Recalcitrant and vegetatively propagated plant species are collectively termed as non-orthodox.

Agriculture research has been started since 1950 in Nepal (Joshi 2017b). APGRs exploration, collection and conservation activities have been initiated since 1984 by the Agriculture Botany Division, Nepal Agricultural Research Council (NARC) in Khumaltar. Taro park, field genebank and community field genebank were established in 2012 to conserve non-orthodox crop species in Pokhara, Khumaltar and Kailali respectively (Joshi 2017a). Aqua pond genebank and livestock farm genebank are in the process of establishment to conserve aquatic and livestock organisms, respectively. Loss of about $50 \%$ of traditional varieties from farmers' field demands immediate action to conserve existing landraces (Upadhyay and Joshi 2003). Two international agreements (CBD 1992 and ITPGRFA 2004) and many national documents eg ADS 2014, NBSAP 2014, Agrobiodiversity Policy 2014, National Agriculture Policy 2004 have given due emphasis to conserve indigenous crop diversity and to promote use.

Total released, registered and denotified varieties are 250, 373 and 35, respectively and among them only $6 \%$ (39 varieties) of the total varieties were developed using 35 local landraces of 17 crops (Pokhrel et al 2017, Joshi et al 2017c, Joshi 2017b). Characterization and pre-breeding of local APGRs are pre-requisite along with making them easy access to breeders and researchers to strengthen the use of these genetic resources in breeding, research, production and trade. Effective conservation methods need to establish at different agro-ecozones involving multi-stakeholders that help to promote use. Objective was therefore to assess the different approaches used to conserve nonorthodox agricultural plant species across the country and discuss their implementation process and advantages. 


\section{METHODOLOGY}

National Agriculture Genetic Resources Center (NAGRC) has been providing technical supports (eg training, guidance, exposure visit, booklet, etc) to different NGOs, farming communities, schools and NARC research stations on conserving non-orthodox agricultural plant species since 2012. Survey and field visit are the key approaches followed in this study. Total 150 farmers and key informants from across the country were contacted. Key informants were identified from many then district agriculture offices, NARC research stations, Department of Plant Resources, Department of Agriculture, LI-BIRD, Parivartan Nepal, Dalchowki, Kailali, Sarlahi, Makawanpur and Lamjung. They were asked for the information related to conservation approaches for non-orthodox plant species. Under the field survey, some NARC research stations, district agriculture offices and government farms were visited. Botanical garden in Godawari and some city parks in Kathmandu were also visited. Three focus group discussions were organized, one in Kathmandu inviting representative from relevant stakeholders, second in Lamjung inviting progressive farmers, representatives from NGOs and district agriculture office, and third in Pokhara inviting representative from research stations and NGOs. Relevant literatures were reviewed. Along with direct interaction, email and telephone were also used to collect and verify the information.

\section{RESULTS AND DISCUSSION}

\section{Classification of APGRs}

Based on the conservation perspective, APGRs are grouped under orthodox and non-orthodox crops (Figure 1). Within non-orthodox, there are three groups, namely intermediate, recalcitrant and vegetatively propagated crops. Orthodox crops are generally stored in seed bank after lowering the seed moisture, whereas non-orthodox are conserved with different approaches. One seed bank may be good enough for storing large number of orthodox samples but, many sites and stakeholders are necessary to manage non-orthodox crops. Because of the sensitiveness of both intermediate and recalcitrant seeds to drying in term of long conservation, NAGRC has grouped all these under nonorthodox and they are conserved with different approaches. About $40 \%$ of the total APGRs in Nepal are non-orthodox.

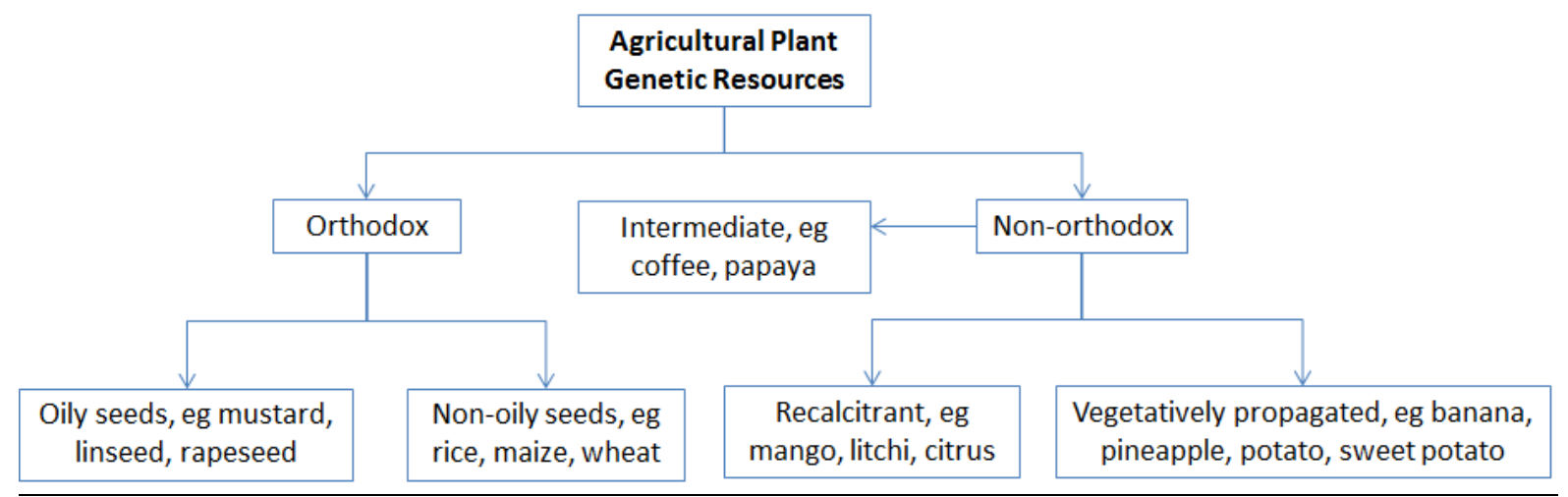

Figure 1. Classification of APGRs based on the seed storage behavior and planting materials (conservation perspective).

\section{Conservation Strategy}

Four conservation strategies ie ex-situ, in-situ, on-farm, breeding have been adopted to manage agricultural plant genetic resources in Nepal (Figure 2). Earlier breeding is mainly focused on developing mono-genotyping varieties and widely adopted, which has a great potential to replace the crop diversity from larger areas. From 2012, breeding work has considered developing site specific as well with diversity within developed varieties using local landraces. In-situ conservation is mainly on natural habitat for crop wild relatives and wild edible plants. On-farm conservation is the system of continue cultivation of local landraces by farmers and targets for landraces in farming land. It also includes the conservation of APGRs available in the command areas of certain organization in their command area eg community seed bank, school field genebank, etc. Ex-situ conservation is the 
conservation of APGRs in areas that are not easily accessible to providers. Within each strategy, there are many methods implemented in the country by different organizations.

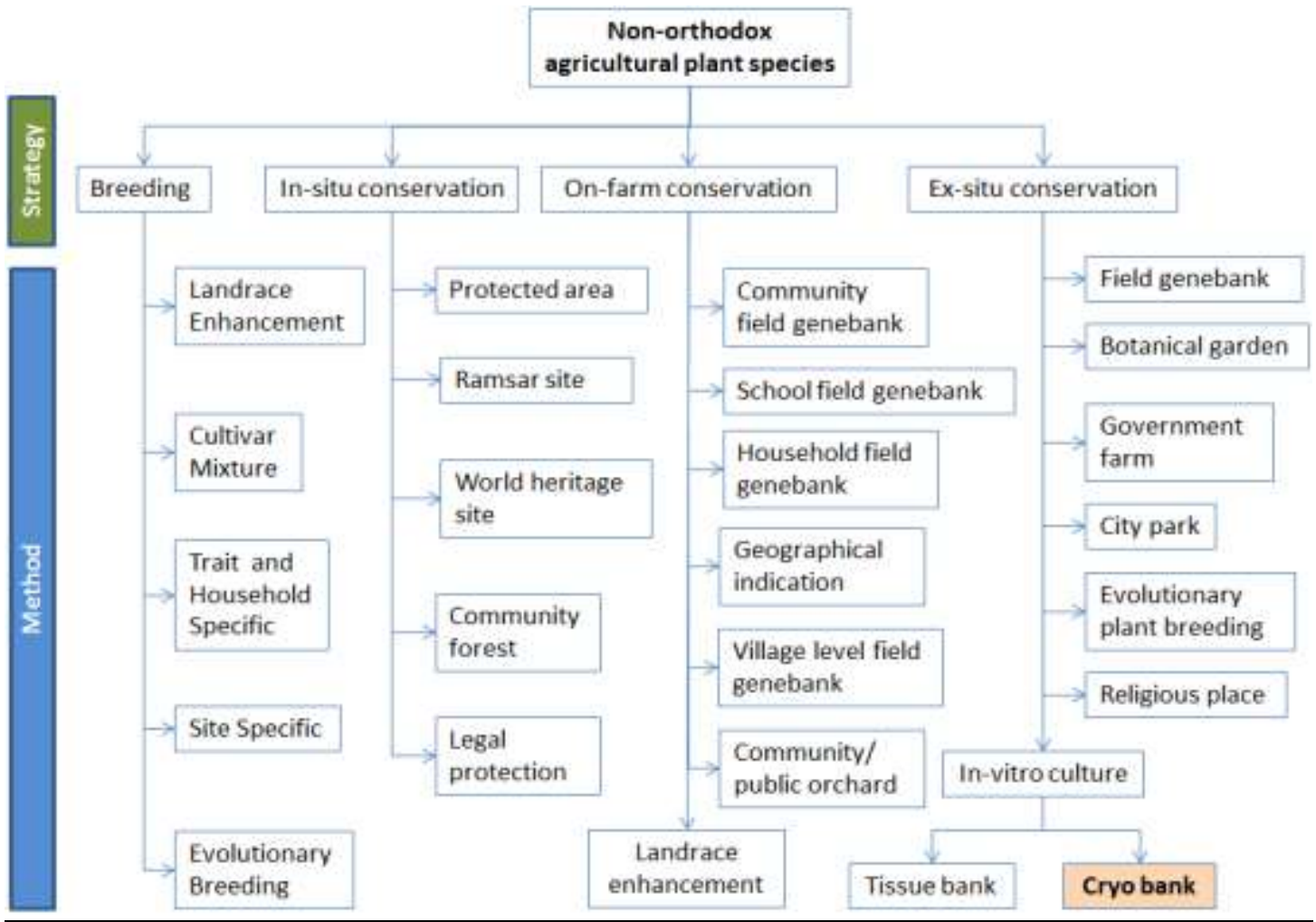

Figure 2. Conservation strategies and approaches for conservation of non-orthodox agricultural plant genetic resources in Nepal (bold approach still not established in Nepal).

\section{Conservation status}

Total existing conservation methods based on the number of sites are given in Table 1 for nonorthodox crops. There are total 19999 conservation sites. The community forest is very high in number followed by religious sites. Majority of these sites is for forest genetic resources along with crop wild relatives and wild edible plants. NAGRC has close collaboration with relevant stakeholders for managing crop wild relative (CWR) and wild edible plant (WEP) and repatriation of lost plant species. APGRs focused conservation approaches are community field genebank, crop specific park, field genebank, government farms, research stations, household field genebank, public orchards, school field genebank, tissue bank and village level field genebank. Such approaches in particular sites were developed very early for forest genetic resources but it is started since 2012 for conservation of APGRs, mainly cultivated crops.

Table 1. Status of conservation approaches for non-orthodox agricultural plant species in Nepal

\section{SN Conservation approach Number Crop species}

\begin{tabular}{|c|c|c|c|c|}
\hline & & & & established year \\
\hline 1. & Botanical garden & 11 & Crop wild relatives and wild edible plants & 1962 \\
\hline 2. & Community field genebank & 3 & Mango, taro, ole & 2012 \\
\hline 3. & Community forest & 19361 & Crop wild relatives and wild edible plants & 1978 \\
\hline 4. & Conservation area & 6 & Crop wild relatives and wild edible plants & 1986 \\
\hline 5. & Crop specific park & 4 & $\begin{array}{l}\text { Taro, ginger + turmeric, sugarcane, potato } \\
+ \text { sweet potato }\end{array}$ & 2012 \\
\hline 6. & Field genebank (public) & 10 & Different species of fruits and vegetables & 2012 \\
\hline 7. & Government fruit farm & 13 & $\begin{array}{l}\text { Different species of fruits (exotic and } \\
\text { indigenous) }\end{array}$ & 1955 \\
\hline 8. & $\begin{array}{l}\text { Government vegetable } \\
\text { farm }\end{array}$ & 10 & $\begin{array}{l}\text { Different species of vegetables (exotic } \\
\text { and indigenous) }\end{array}$ & 1952 \\
\hline 9. & Household field genebank & 50 & Different species of fruits and vegetables & 2016 \\
\hline
\end{tabular}




\begin{tabular}{|c|c|c|c|c|}
\hline SN & Conservation approach & Number & Crop species & $\begin{array}{c}\text { First } \\
\text { established year }\end{array}$ \\
\hline 10. & Hunting reserve & 1 & Crop wild relatives and wild edible plants & 1987 \\
\hline 11. & NARC research station & 38 & $\begin{array}{l}\text { Domesticated crop species (exotic and } \\
\text { indigenous) }\end{array}$ & 1991 \\
\hline 12. & National park & 10 & Crop wild relatives and wild edible plants & 1973 \\
\hline 13. & City park & 5 & $\begin{array}{l}\text { Few crop wild relatives and wild edible } \\
\text { plants }\end{array}$ & Not known \\
\hline 14. & Public orchard & 100 & Mango & Ancient time \\
\hline 15. & Ramsar site & 9 & Crop wild relatives and wild edible plants & 1987 \\
\hline 16. & Religious place & 350 & $\begin{array}{l}\text { Few crop wild relatives and wild edible } \\
\text { plants }\end{array}$ & Ancient time \\
\hline 17. & School field genebank & 3 & Banana, sugarcane, citrus & 2014 \\
\hline 18. & Tissue bank & 6 & $\begin{array}{l}\text { Potato, sweet potato, banana, cardamom, } \\
\text { sugarcane }\end{array}$ & 2013 \\
\hline 19. & $\begin{array}{l}\text { Village level field } \\
\text { genebank }\end{array}$ & 2 & Banana, pineapple & 2014 \\
\hline 20. & Wildlife reserve & 3 & Crop wild relatives and wild edible plants & 1976 \\
\hline 21. & $\begin{array}{l}\text { World heritage site (natural } \\
\text { and cultural) }\end{array}$ & 4 & $\begin{array}{l}\text { Few crop wild relatives and wild edible } \\
\text { plants }\end{array}$ & 1979 \\
\hline
\end{tabular}

Sources: Joshi 2017b, Genebank 2016, Bhattarai 2016

\section{Conservation Approaches}

In the past conservation of non-orthodox species is mainly through vegetative parts which narrow the genetic base and arrest the meiosis based diversity. Therefore, NAGRC has considered conservation of both vegetative based as well as meiosis based propagules. One of the target of conservation is acceleration and conservation of natural evolution. Database of non-orthodox plant species conserved in different methods are very poorly documented and utilized in research. Database of existing nonorthodox APGRs need to update and make online searchable. All such approaches should consider red zoning and red listing mechanism for priority conservation.

Field genebank: Maintenance of non-orthodox APGRs in the fields is called Field Genebank. Field Genebank (collections of crop diversity) is an ex-situ and dynamic system of conservation for vegetatively propagated crop species and species with recalcitrant seeds (seeds that can't be dried below $12 \%$ moisture). It is more or less similar to diversity blocks, conserving and maintaining as much diversity as possible in a minimum samples. Field Genebank has many advantages eg crop diversity conservation, production and income generation, sources of propagating materials, making healthy environment, resources for research and study, providing diversity options and selection opportunity, access to all from anywhere and materials for pre-breeding and breeding, etc. Field Genebank is not only for conservation, production and distribution; it is considered as learning and recreational center.

Government horticultural farms: Majority of government horticultural (vegetables and fruits) farms have also considered conservation of locally available agricultural genetic resources. Such farms should focus on conservation and use of local domesticated plant species, crop wild relatives and wild edible plants available in their vicinity. Nursery should be of such genetic resources to make available to all visitors, farmer and researchers. Profile of conserved local APGRs should be published along with maintenance of passport and characterization database. 


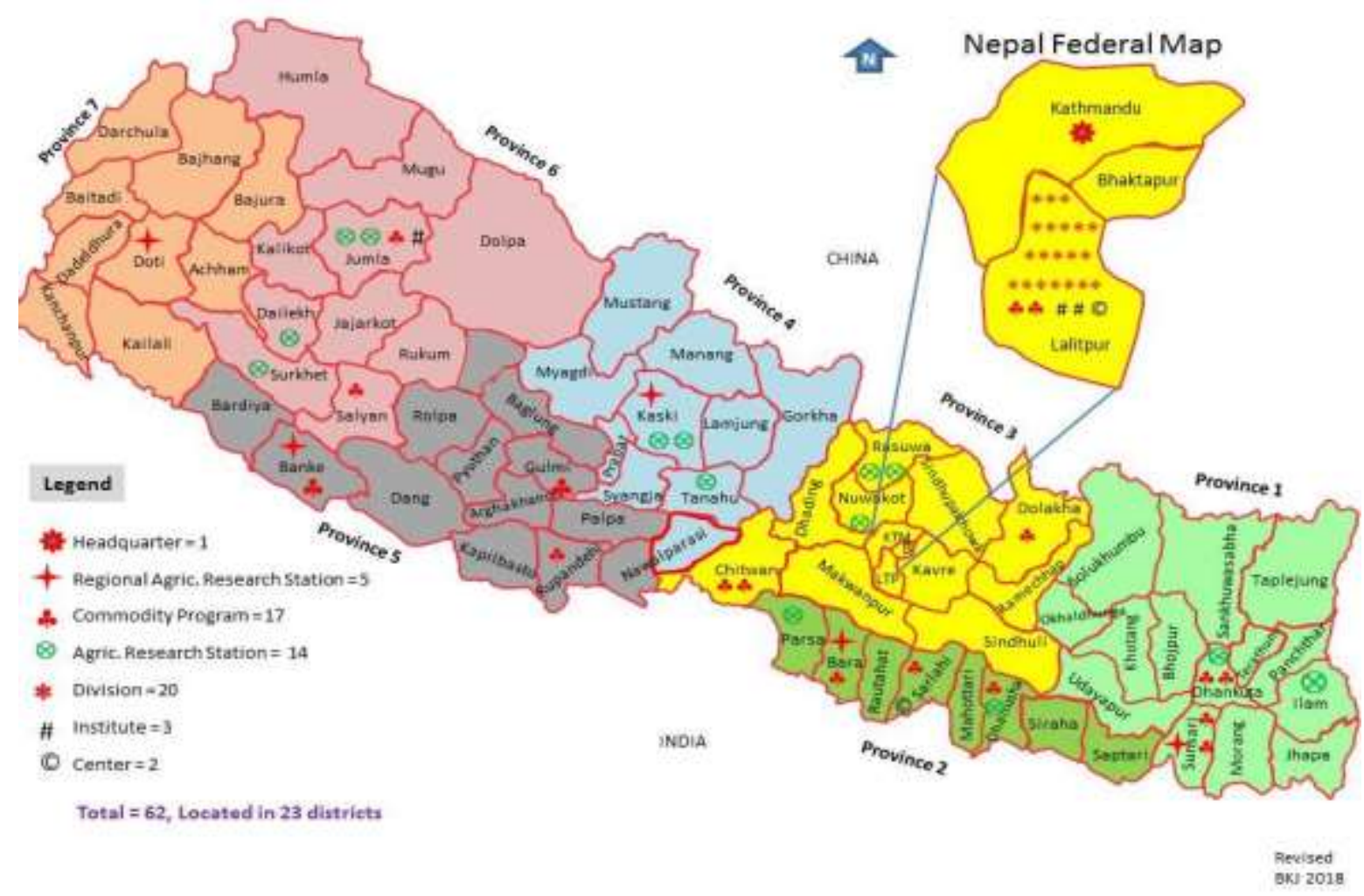

Figure 3. Research stations of NARC where, field genebanks have been initiated to establish for non-orthodox agricultural plant species available in their command areas.

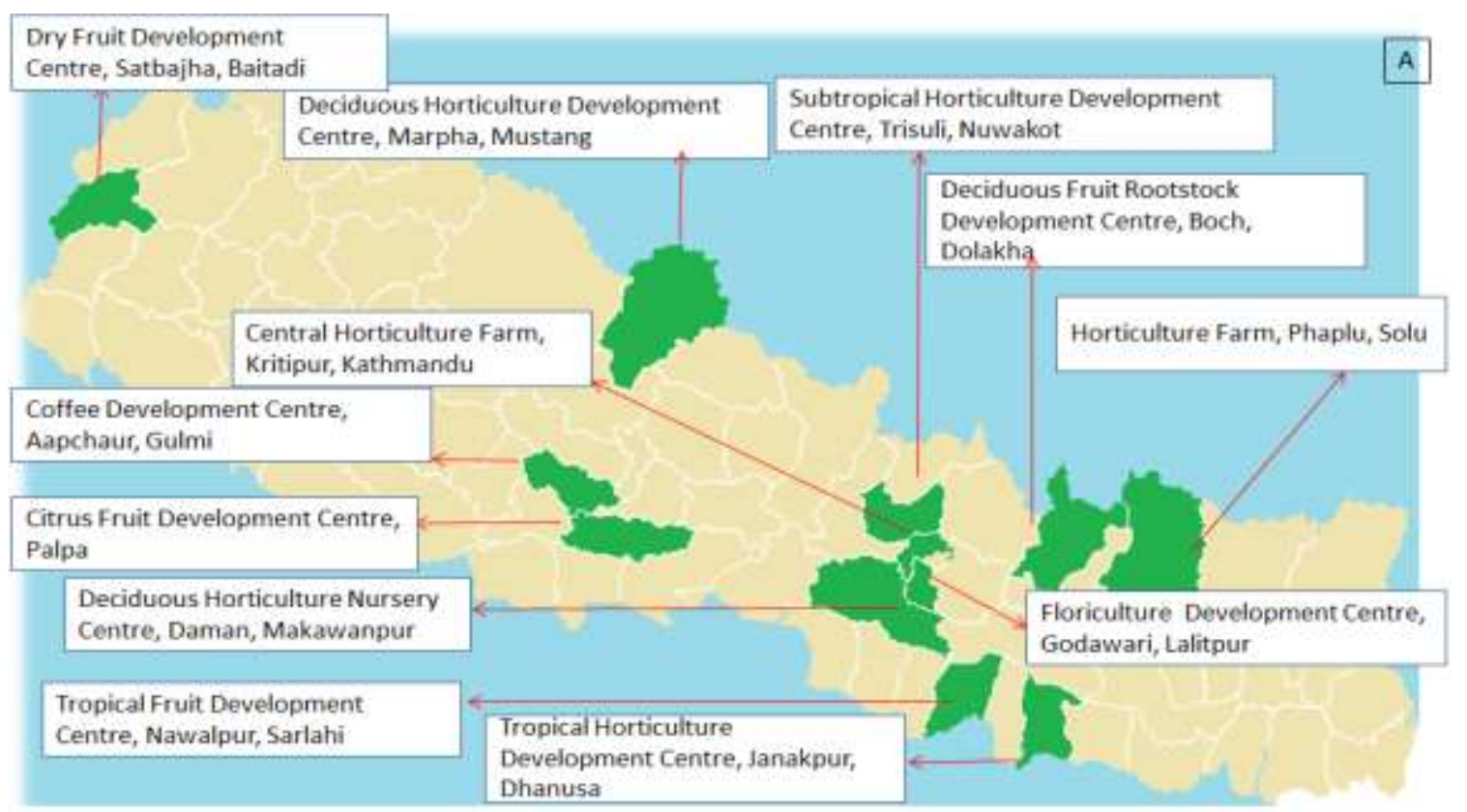




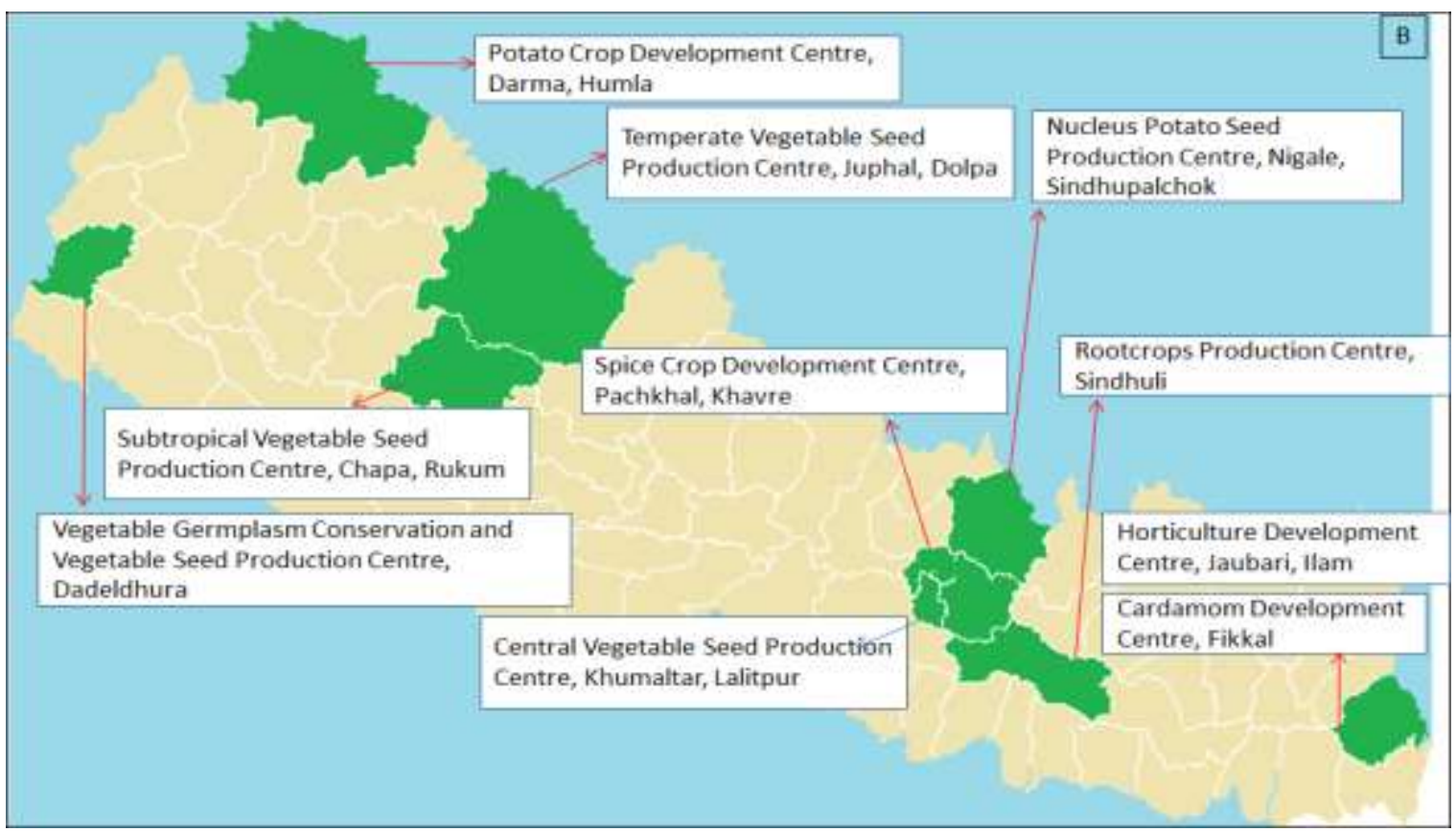

Figure 4. Horticulture farms (A. Fruits, B. Vegetables) of Department of Agriculture, that needs to establish field genebank considering the conservation of locally available non-orthodox plant species.

Source: Bhandari et al 2017.

Landrace enhancement: Genetic enhancement of landraces is necessary to make them competitive and for continue cultivation on-farm. It is on-farm research led by farmers and is basically based on participatory selection of genotypes. This is for conservation through use. Identification of trait deficit in local landrace is recognized and effort is made on improvement in such trait. It is assumed that enhanced landraces are well accepted by farmers and keep continued cultivation of such landraces that help for long term conservation.

Cultivar mixture: Mixture of two or more than two landraces together and growing in the field helps to conserve many landraces within a small area. This is very common practices for many orthodox crop species; however, same practice need to apply for non-orthodox plant species. This system not only supports conservation but also helps to buffer against biotic and abiotic stresses. It also accelerates evolution and provides diversity option for selection. Mixture is based on the principle of using cultivars with diversified functions to limit the development of diseases. Functional diversity leads to higher stability (Petchey and Gaston 2002). It support for prolonging the useful life of resistance genes and increasing the crop productivity by taking into account the functional differences in disease resistance and other agronomic traits of cultivars. Mixing existing cultivars with more diverse genetic backgrounds than multilines can enhance functional diversity and improve yield by providing more chances for positive interactions among cultivars. Mixture cultivation is commonly used by many farmers in Nepal. Farmers grow several cultivars in a field or adjacent field as a strategy to cope with heterogeneous and uncertain ecological and socioeconomic conditions.

Site, trait or household specific variety: This is one of the conservation breeding approach that support for growing larger number of different landraces and varieties. Earlier, there is trend of developing and growing wide adapted variety or landrace which generally cover large areas (monogenotype in larger area). This is necessary to consider during varietal development program because of different climate in growing sites, different demand or choices of farmers and consumers. This strategy provides options of landrace diversity and favor conservation by growing different landrace or variety by different farmers in different localities.

Evolutionary plant breeding: Evolutionary plant breeding (EPB) is the maintaining and creating high level of genetic diversity in crop population for production. It includes planting a much larger mixture of hundreds or thousands of different varieties, and do not necessarily aim to arrive at single 
varieties and mainly focus on natural selection. EPB is effective for any problem/ any target, which consider agricultural biodiversity and create continued evolution and selection. Evolutionary population is very important for uncertainty, eg drought problem, diseases problem, insect problem, changes in temperature, rainfall, air circulation, nutrient depletion, low yield, multiple objectives, varietal dependency, etc. One of the conservation strategies of NAGRC is evolutionary plant breeding for conservation of intra-landrace diversity on-farm. EPB has been applied in Jumli Marshi rice and similar approach needs to apply for other non-orthodox crop species. Based on the source of diversity used in EPB, there may be two different types of populations. One is called Composite Cross Population (CCP), developed through crossing among different selected parental lines. Second is varietal mixture, which is simply the physical mixing seed of existing varieties. Both are evolving populations. The frequencies of different genotypes in the population change from season to season, depending on the genetic variation available and the strength and direction of environmental variables. For mixing cultivars, traits combination is the major consideration. Discussion should be made on selecting germplasm based on different traits targeting to minimize the abiotic and biotic stresses. Vertical and horizontal spaces should be targeted to use as much as possible. Different contrast traits need to consider.

Geographical indication: There are many location specific products which is better in term of quality comparing with products of other area. Such geo-linked trait has been evolved due to the continue cultivation of particular genotype over the decades by the farmers. Underestimating such value, there are now many cases of replacing such genotype by introduced modern varieties. If one can get advantage of growing such landrace that has some geographically linked gene expression, this landrace can be grown continuously and there will no risk of losing genotypes. Geogrpahical indication should be in priority for both conservation as well as for harvesting economic benefits. Some crop landraces have been described in associated with geographical indication by Joshi et al (2017b).

Community field genebank (CFGB): It is part of the community genebank, where community conserves non-orthodox plant diversity following the working modality of community seed bank. All available local plant diversity of non-orthodox are managed by community at certain sites which can be public land or private land. The community in Gadhariya, Kailali has established CFGB with 76 accessions of mango in 5.5 ha of land. Similar kind of work has also been started in Kachorwa, Dalchowki, Purkot and other many areas.

School field genebank: Many school, college and university have fallow land that can be used to conserve local APGRs. Maintaining local non-orthodox plant genetic resources around school or university is called school field genebank. In such genebank, students involve for germplasm collection, growing, caring and characterizing them, therefore support for education or research materials, enhance environment and provide harvest. Students can collect germplasm along with passport data from their own home during vacation. It is very effective means of conserving APGRs and enhancing understanding and value of these resources to students, teachers and visitors.

Village level field genebank: In this approach, each household in a village maintain different landraces in their private land and together at village level, diversity of particular plant species at landrace level conserved, used and distributed. It is established in Makawanpur for taro and banana. Village enjoys the rich diversity and farmers can share, sale harvest. Diversity from other areas can also be added and database should be maintained at community level, mainly focusing what diversity is being maintained by each household.

Community/ public orchard: Mango diversity is commonly conserved through public orchard (Upadhya et al 2017). However, most of such orchards are very old (Figure 5) and rejuvenation is urgent for conservation of diversity being maintained in public orchard across the country. Public orchard should be converted to community field genebank and managed in the principle of community forest. Relocation of such diversity from red zone areas has been initiated along with rejuvenation in some community own areas. Both scion and seed have been used for maintenance of diversity. 
Protected area: This is government protected areas and huge amount of money and experts are invested in such system. However, APGRs are not generally talked in such protected areas. Many CWR and wild edible plants are endangered and therefore, priority should also be given to such APGRs for lost cost conservation. NAGRC has started to work with protected areas for conservation of APGRs.

Ramsar site: Conservation effort for aquatic agricultural genetic resources is very minimal. Natural resources are being conserved in Ramsar sites. APGRs also need to include in such sites.

World heritage site: These sites always got priority for conservation of forest genetic resources along with natural and human made valuable structure or resources. NAGRC has initiated to consider APGRs for conservation in such areas. Such site should consider APGRs available around the site for conservation.

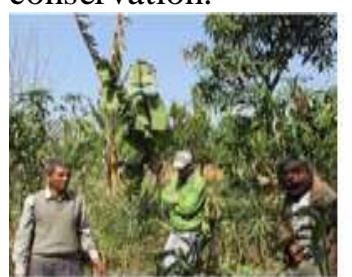

Household field genebank, Sarlahi

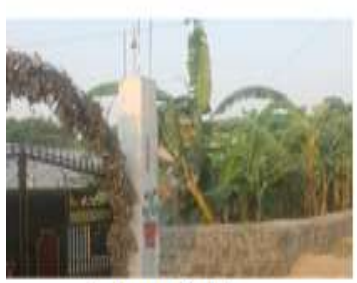

School field genebank, Lamjung

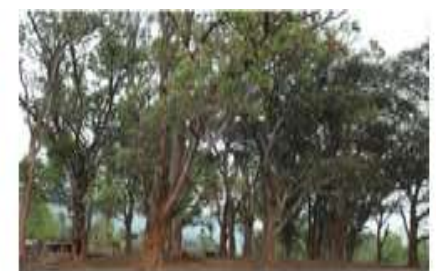

Public mango orchard, Lamjung

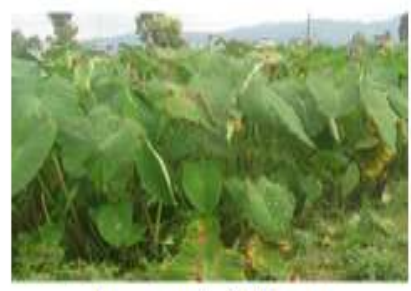

Taro park, Pokhara

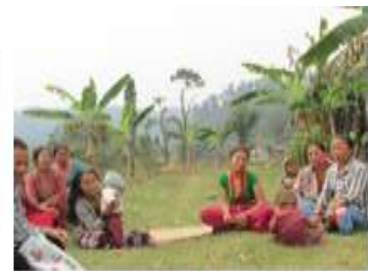

Village level field genebank, Makawanpur

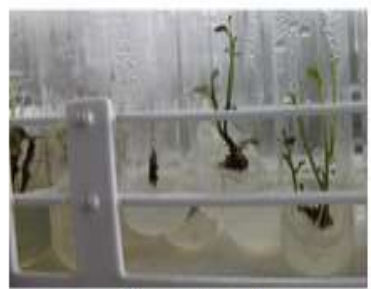

Tissue bank, Khumaltar

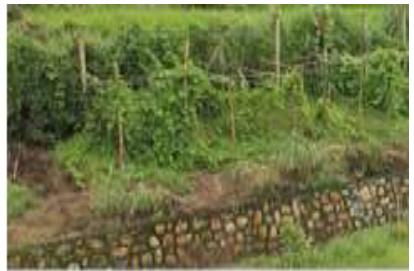

Public field

genebank, Khumaltar

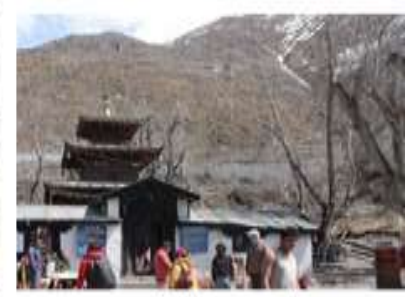

Religious place, Muktinath

Figure 5. Different types of field genebanks and approaches for conserving non-orthodox agricultural plant species in Nepal.

Community forest: Community forest has contributed to biodiversity conservation. About 15 plant species are being conserved through community forest, though there are many community forests. Communities need to encourage for considering plantation and conservation of all types of APGRs in community forest. Pandey (2007) found comparatively higher tree species diversity on communitymanaged forest stands than the national parks and government managed forests.

Legal protection: Some forest plant species are legally protected (ie not allowed to cut, collect, sale or commercialize or export). Such system should also be applied not only at species level but also at landrace level of APGRs. Red zoning and red listing system need to consider for implementation of legal protection of landraces.

Botanical garden: Generally forest and flower genetic resources are maintained in Botanical Garden. Few crop wild relative and wild edible plants are found in some gardens. All kinds of indigenous APGRs should be grown and maintained in such gardens that meet the objective of garden as well as conservation. This is also a kind of field genebank and database should be generated.

City park: Growing of APGRs in parks located in the cities are called city park for conservation. Very few APGRs are conserved in city park. Local landraces of crop species as well as crop wild relative and wild edible plants should be considered to grow in such park so that it can support conservation and enhance the value and understanding of local genetic resources. 
Religious site base field genebank: All religious sites in Nepal are culturally protected and plant species therefore within such sites are automatically protected and conserved in long run. About 40 plant species mainly crop wild relatives and wild edible plants are being conserved in such sites located across the country. Initiation has been taken also to include domesticated plant species in such site as religious site based field genebank. Banana is the most common species conserved in religious sites. Coconut, sweet potato, yam and aamala etc are other religious crops. Communities are also encouraged to consider such site for protection of all kinds of agricultural plant genetic resources.

In-vitro culture: Conservation of vegetative parts, mainly meristem shoot in test tube (ie through tissue culture) keeping in slow growth condition is the technique of in-vitro method of conservation. Maintenance of diverse genetic resources following such method is called Tissue Bank. This technique is very effective for conserving those crop species, which either produce recalcitrant seeds or does not produce any seeds. Plantlets can be kept in test tubes on nutrient medium for indefinite periods of time by transferring at regular interval. It requires little space for preservation of a large number of crop landraces. Plantlets are maintained in an environment free of pests or pathogens and can easily be kept free from viruses, insect parasites, fungi or bacteria. Because of such advantages, in-vitro tissue culture has been initiated in about 5 different organizations. They are conserving about 10 plant species through Tissue Bank. Cryopreservation is also expected for long term conservation of non-orthodox species.

\section{Components in the Field Genebank}

To make field genebank more productive and effective, different components are needed to establish. Field genebank in research stations and community (ie community field genebank) have established 10 components as listed in Figure 6 under field genebank. One of the much appreciated components is to make living fences and hedge row from APGRs. These components have multi-function eg fencing, beautify, harvest and conservation. Compost pit is generally for composting weeds, pruned branches and other degradable items, so that nutrients can be recycled. Database, information and learning center is very effective in community field genebank. Visitors and users are highly benefited from this component. Nursery is for distribution of collections as well as to replanting. Short term storage is simple ambient condition to store planting materials for one season eg garlic bulbs, ginger rizhomes, etc. Image bank (both print and electronic album) and herbarium are useful for identification and selection even during off season time, if someone visits the sites. Crop specific park becomes attractive because of large number of different landraces in a single location. This also accelerates the evolution, favoring development of climate resilient varieties. Processing and drying unit is for handling planting materials for distribution, planting, storing and database development. Exhibition is like a museum that is useful to manage duplicates, to identify, to see diversity, to look on collection sites, etc.

\section{Database management}

In the road from collection to maintenance to research of any accession, different types of data are generated and they are must for advancing research as well for trace backing and trace forwarding the accession. Different eight kinds of data documentation are being maintained in field genebank (Figure 7). Descriptors are developed for crops based on the farmers and scientific knowledge. Many descriptors are available but to meet the local and national needs, there are necessary to have own system considering these international descriptors. Passport data format has been developed and passport data for each collection is collected. They are mostly filled asking farmers or donors. Based on the passport data and stability in the field, accession number is assigned and then this accession is handled through this number. Based on the descriptors, characterization data at both phenotypic and genotypic levels are generated and maintained for each accession. This data is very useful for researchers and farmers to select the materials. One of the main targets of field genebank is to distribute germplasm for research and production free of cost and make available for ever to all. Each season, many planting materials are distributed many times. Such distribution data along with availability of planting materials in the field are maintained and called stock management data. It is basically useful for knowing how much planting materials one have and how much one need to multiply. Among the collections, which one is better than other for a particular trait is determined 
through evaluation and data generated from such trial are maintained in the name of evaluation data. Genotypic data is developed using DNA markers eg DNA finger print, genetic diversity, etc. DNA is extracted from each accession and stored in DNA bank for further research and distribution. Images of different parts of accession are prepared and maintained both in hard and soft copies. Some of field genebanks have started generating all these data in coordination with NAGRC.

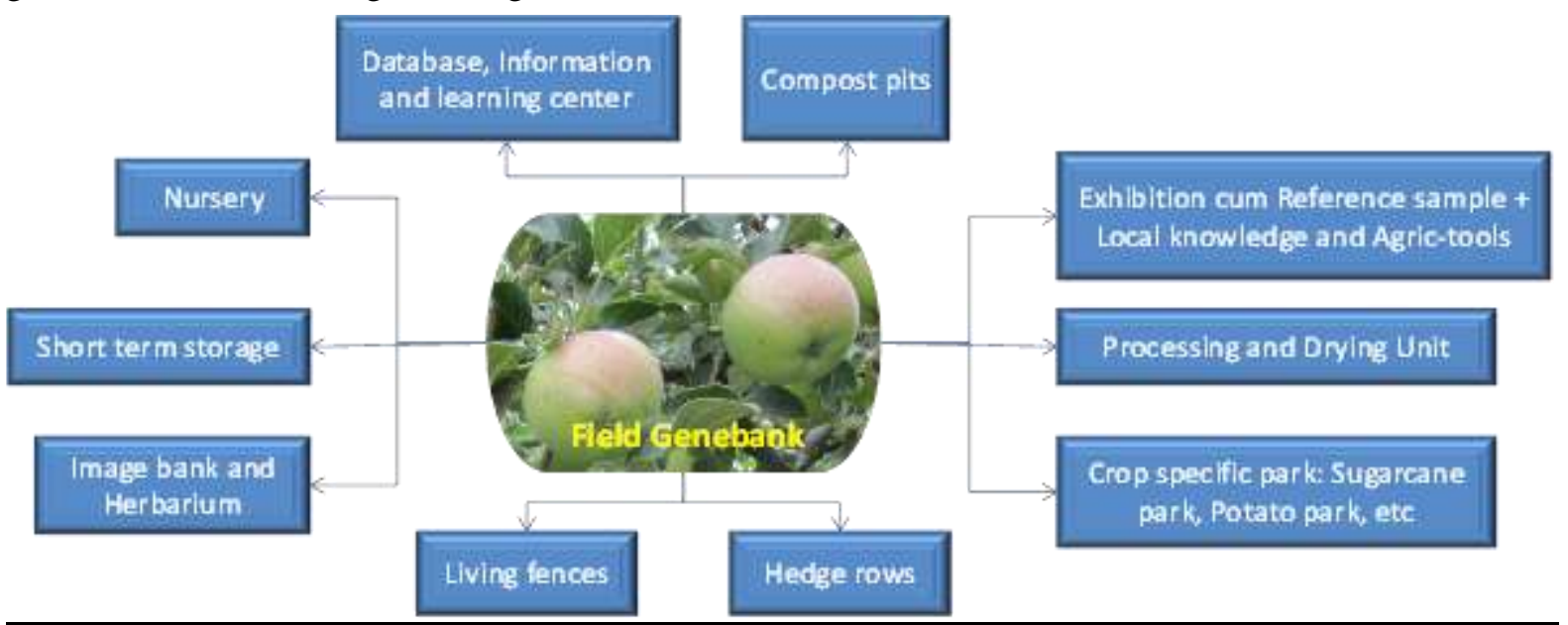

Figure 6. Components in the Field Genebank (Horizontal and vertical space utilization).

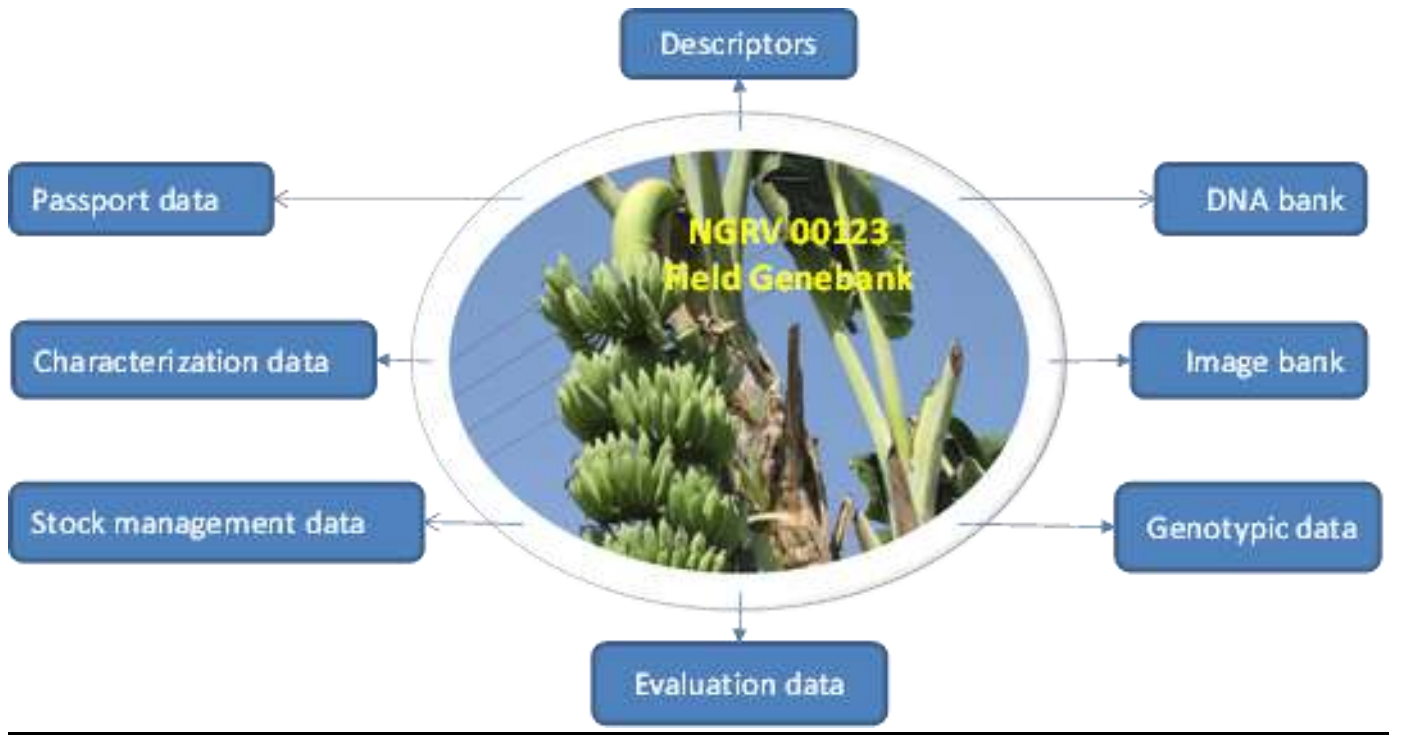

Figure 7. Different types of data for each collection (accession).

\section{Utilization}

Field genebank is for conservation to use at current or in future. It is a single site from where, large number of diversity can be observed, a window to see the crops diversity. Use values are also different of different types of field genebank (Figure 5). They are mostly for researchers, students, farmers and users. It has multipurpose uses in addition to conservation and environment improvement. For example, household field genebank is basically for meeting the household demands, to sale and to improve the environment. Community field genebank and mango orchards are to generate income, to have different test fruits. School field genebank is for study and harvest. Village level field genebank is for household requirement as well as for sale. Crop specific park is mainly for providing selection opportunity and creating environment to accelerate the evolution. Tissue bank is for distribution and religious site based field genebank is for creating area more attractive. Such field genebank also attract birds and wild life in addition to providing some eating parts.

\section{CONCLUSION}

Most of the non-orthodox plant species are perennial and therefore need field for conservation. Any fallow areas, public areas, around public buildings, river, temple and along the road are suitable for 
conservation of non-orthodox species, that ultimately helps to sustain the agriculture and its associated life. All relevant stakeholders including farming communities should be involved for conserving such genetic resources. These resources should be maintained with the minimum input, mixing together with minimum spacing creating favorable environment to maximize the interaction with nature. Database of such materials should be available online so that users can select and study materials online for further research and use. Conservation through use is the main principle for long term conservation of non-orthodox plant species.

\section{ACKNOWLEDGEMENTS}

This is an outcome of AFACI funded project, Integrated Management System of Plant Genetic Resources. I would like to thank Sanjeev K. Rai, Sishir Panthi, DoPR; Hari B. KC, NCPVSC; Anil K. Acharya, MoAD; Indra R. Pandey; Ramita Manandhar, FDD; Dinesh K. Shrestha, Parivartan Nepal; Deepak Upadhaya, LIBIRD for providing information.

\section{REFERENCES}

Bhandari D, R Manandhar, HB KC and MP Paudel. 2017. Government Farms and Agricultural Plant Genetic Resources. In: Conservation and Utilization of Agricultural Plant Genetic Resources in Nepal (BK Joshi, HB KC and AK Acharya, eds). Proceedings of $2^{\text {nd }}$ National Workshop, 22-23 May 2017, Dhulikhel. NAGRC, FDD, DoA and MoAD Kathmandu; pp.115-127.

Bhattarai B. 2016. Community Forest and Forest Management in Nepal. American Journal of Environmental Protection 4(3):79-91. DOI: http://dx.doi.org/10.12691/env-4-3-3.

Genebank. 2016. Annual Report 2072/73 (2015/16). National Agriculture Genetic Resources Center (BK Joshi, KH Ghimire and D Singh, eds. NAGRC, Khumaltar.

Hong TD, S Linington and RH Ellis. 1996. Seed Storage Behaviour: A Compendium. Handbooks for Genebanks No. 4. International Plant Genetic Resources Institute, Rome.

Joshi BK, MR Bhatta, KH Ghimire, M Khanal, SB Gurung, R Dhakal, and BR Sthapit. 2017c. Released and Promising Crop Varieties of Mountain Agriculture in Nepal (1959-2016). LI-BIRD, Pokhara; NARC, Kathmandu and Bioversity International, Pokhara, Nepal.

Joshi BK, MR Bhatta, KH Ghimire, P Chaudhary and D Singh. 2016. Mapping and measuring the flow and interdependence of plant genetic resources. In: Implementing the International Treaty on Plant Genetic Resources for Food and Agriculture in Nepal: Achievements and Challenges (BK Joshi, P Chaudhary, D Upadhya and R Vernooy, eds). LIBIRD, Pokhara; NARC, MoAD, Kathmandu and Bioversity International, Rome; Nepal; pp. 28-52.

Joshi BK. 2017b. Plant Breeding in Nepal: Past, Present and Future. Journal of Agriculture and Forestry University 1:1-33.

Joshi BK. 2017a. Conservation and utilization of agro-biodiversity advanced from 1937 to 2017 in Nepal. In: Krishi Sanchar Smarika (F Devkota, ed). Agricultural Information and Communication Center (AICC), MoAD; pp.181-208.

Joshi BK, AK Acharya, D Gauchan and MR Bhatta. 2017a. Agrobiodiversity status and conservation options and methods. In: Conservation and Utilization of Agricultural Plant Genetic Resources in Nepal (BK Joshi, HB KC and AK Acharya, eds). Proceedings of $2^{\text {nd }}$ National Workshop, 22-23 May 2017, Dhulikhel. NAGRC, FDD, DoA and MoAD, Kathmandu; pp.21-38.

Joshi BK, D Singh, P Chaudhary, KH Ghimire and M Khanal. 2017b. Biotechnology, geographical information system and climate analog tool for management of APGRs. In: Conservation and Utilization of Agricultural Plant Genetic Resources in Nepal (BK Joshi, HB KC and AK Acharya, eds). Proceedings of 2nd National Workshop, 22-23 May 2017, Dhulikhel. NAGRC, FDD, DoA and MoAD; pp.21-38.

MoFSC. 2014. Nepal biodiversity strategy and action plan 2014-2020. Government of Nepal, Ministry of Forests and Soil Conservation, Kathmandu, Nepal.

Pandey SS. 2007. Tree species diversity in existing community based forest management systems in central mid-hills of Nepal. Uppsala, Sweden: Swedish Biodiversity Centre. Swedish University of Agricultural Sciences

Upadhya D, BK Joshi, R Dhakal, R Manandhar, AK Acharya and A Sharma. 2017. Community and public orchards, and community and school field genebanks in Nepal. In: Conservation and Utilization of Agricultural Plant Genetic Resources in Nepal (BK Joshi, HB KC and AK Acharya, eds). Proc. 2nd Nat. Workshop, 22-23 May 2017, Dhulikhel. NAGRC, FDD, DoA and MoAD, Kathmandu, pp.102-114.

Upadhyay MP and BK Joshi. 2003. Plant Genetic Resources in SAARC Countries: Their Conservation and Management: Nepal Chapter. SAARC Agriculture Information Center; pp.297-422.

$|1-----||------1|$ 